Improvement and extension of food technology. The development of food technology on an industrial scale is desirable, but, at the present time, the economic, social and industrial situation in Turkey makes it difficult. The improvement and expansion of traditional methods of processing is, however, practicable and should receive increasing attention. The modification of methods of sun-drying so as to reduce losses of riboflavin should be studied. The traditional methods of air-drying of meat, fish, tarhana and vegetables could easily be extended and modified to provide a simple and cheap means of increasing supplies of protein of good quality.

Education in nutrition. Essentially, in applied nutrition work in predominantly rural communities, there are two objectives to be achieved: (a) good housewifery and (b) good husbandry. Mothers must be taught to feed themselves and their children properly and food producers must do all they can to increase supplies. Such education should be planned at the village level in fulfilment of a well-considered national food and nutrition policy.

\title{
REFERENCES
}

Dogramaci, I. \& Wray, J. D. (1959). Turk. F. Pediat. I, 128.

Erzin, N. (1956). Turk. Bull. Hyg. exp. Biol. 16, no. 2, p. 137.

FAO (1958). Food Balance Sheets (1954-56 Average). Rome: Food and Agriculture Organization of the United Nations.

Platt, B. S., Miller, D. S. \& Payne, P. R. (196I). In Recent Advances in Human Nutrition. [J. F. Brock, editor.] London: Churchill.

Thomson, J. C. (1956). Report on a Nutrition Survey in Turkey. Geneva: World Health Organization.

\section{Problems and some solutions: Iraq}

By W. Frankul, Human Nutrition Research Unit, National Institute for Medical Research, The Ridgeway, Mill Hill, London, N.W.7

Iraq is one of the countries of the Near East, which also includes Egypt, Syria, Lebanon, Palestine and Saudi Arabia. These countries have similar dietary, socioeconomic and cultural patterns. Iraq has a total area of nearly half a million $\mathrm{km}^{2}$. - Most of the country is a semi-arid plateau. The better agricultural land is found along the rivers Euphrates and Tigris. Rainfall, generally confined to the period November-April, is heavy in the north but scanty in other parts of the country. Iraq has a population of about 7 million, $70 \%$ rural, $10 \%$ nomadic and the rest urban; $90 \%$ of the population is illiterate.

Over half of the national income is derived from agricultural products; the rest comes from the mineral-oil industry and some minor industries. Three-quarters of the population are fellaheen (peasants and farmers). The annual income is between $£ 35$ and $£ 45$ per person. The main agricultural products are dates, wheat, maize, barley, cotton and grain legumes. Adolph (1954) estimated the areas of land in the Near East (expressed as percentages of the total arable land) under various crops as: wheat 30 , barley I2, maize I I, rice 8 , grain legumes 5 , sorghum 4 . 
In Iraq, vegetable production is low because of poor marketing facilities. The livestock population is small and of low productivity, partly because of lack of veterinary care. Cattle are used mostly as draught animals and beef is of poor quality. The dairy and poultry industries are of minor importance. Most of the milk from sheep and goats is made into cheese, butter and yogurt in the villages and sold in the towns and cities.

\section{Pattern of diet, and deficiency diseases}

There is only scanty information on the food consumption and nutritional status of the people of Iraq. Food balance sheets (FAO, I958) show that the energy value of the total food supplies is 2000-2500 kcal/head day. Jalili, Georges \& Fadhil (I950) reported that the daily calorie intake of the lowest-income group of the population was I 500-I $700 \mathrm{kcal} /$ head.

A comparison of the patterns of the diet of Iraq, the Middle East, the U.K. and the U.S.A. is given in Table I. This table shows that the Iraqi diet consists mainly of cereals and grain legumes and is markedly low in fat and protein of animal origin.

Table I. Percentage of total calorie value of diet derived from various foods in Iraq, the Middle East, the U.K. and the U.S.A. (FAO, 1958)

\begin{tabular}{|c|c|c|c|c|}
\hline Food & Iraq & $\begin{array}{c}\text { Middle } \\
\text { East }\end{array}$ & U.K. & U.S.A. \\
\hline Vegetables & 4 & 12 & 10 & I4 \\
\hline Sugar & 8 & 3 & 12 & Io \\
\hline Fat & $4 \cdot 5$ & 7 & 14 & I0 \\
\hline Cereals and legumes & 73 & 75 & 35 & 38 \\
\hline Meat and animal products & $x \cdot 5$ & 2 & 18 & $2 \mathrm{I}$ \\
\hline Milk & 6 & 3 & 12 & 9 \\
\hline Dates & 3 & - & - & - \\
\hline
\end{tabular}

However, in the annual report of the Ministry of Health (Iraq Ministry of Health, 1958) there is scarcely any reference to the occurrence of malnutrition in Iraq. On the other hand, other workers report that malnutrition is common. Studies made by Jalili et al. (1950) revealed that the total intakes of protein, B-vitamins and minerals in the lowest income group were below the daily recommended BMA allowances (British Medical Association: Committee on Nutrition, 1950). Cases of paralysis which have responded to the administration of nicotinic acid and riboflavin have been reported (Al Witry, Shaby \& Kantarjian, 1950). Gounelle, Demarchi, Rabii, Rashid, Findakly, Selloumi \& Cofman (1956) showed that the levels of nicotinic acid in the blood of groups of Iraqi army and police personnel examined in Baghdad were below those of Europeans; and that the levels of protein, calcium, vitamin A and riboflavin in their diets were below those recommended by the BMA. Gounelle \& Demarchi (1953) observed that growth curves of Iraqi infants were below those of European infants; they attributed this finding to breast feeding by malnourished mothers. Parasitic disease, by impairing the utilization of protein for physiological purposes, and gastro-intestinal bacterial infections associated with malnutrition 
contribute to the high incidence of nutritional anaemia (Jalili \& Demarchi, 1952; Demarchi, 1958), to the prevalence of protein malnutrition (Salman Taj El Din \& Al Jawad, 1956) and to liver cirrhosis (Stacy, 1944).

The staple food in Iraq is bread; the well-to-do and the majority of city-dwellers eat wheat bread prepared from low-extraction flour. The majority of peasants and bedouin in the northern part of the country eat mixed (barley and wheat) or barley bread. In the south the bread is made from millet (Setaria sp.) and rice. Rice is the second most important staple in the diet in the central and southern parts of Iraq, whereas parboiled wheat, known as burghal, is the second most important item in the north. Dates are available in large quantities and are much eaten by poor people. Mutton, which is the meat of choice, and fish are available to the well-to-do families. Okra (Hibiscus esculentus) is used frequently most of the year. Ghee and butter were the fats most commonly eaten but nowadays hydrogenated oil is replacing them.

Kushik, which is essentially a yogurt-burghal mixture, is eaten in large quantities in the rural areas of Iraq. It is made by the villagers by mixing one part by weight of dried parboiled wheat grits with two parts of yogurt, and fermented for a week. Curd from an equal volume of milk is then added and the whole is fermented for a further period of $4-5$ days. The product is sun-dried and ground to a powder which can be stored for a long period. Van Veen (r957) pointed out the importance of this product in rural areas in the Middle East. Frankul \& Pellett (r959), examined its nutritive value and showed that it is rich in most of the B vitamins (Table 2). Kushik prepared in Iraqi villages was found to be low in riboflavin, which is destroyed when kushik is dried in the sun. Animal experiments at this Unit showed that the net protein utilization (standardized) (N.P.U.(st)) of kushik is high $(76 \%)$, indicating a supplementary effect between the amino acids of the wheat (N.P.U.(st) $=40 \%$ ) and the milk (N.P.U.(st) $=76 \%$ ), the deficiency in lysine, the limiting amino acid of the wheat, being made up by the milk.

\section{Table 2. Some constituents of kushik}

\begin{tabular}{|c|c|c|c|c|c|c|c|}
\hline & $\begin{array}{l}\text { Moisture } \\
(\%)\end{array}$ & $\begin{array}{l}\text { Protein } \\
\text { (g) }\end{array}$ & $\begin{array}{l}\text { Fat } \\
(\mathrm{g})\end{array}$ & $\begin{array}{l}\text { Thiamine* } \\
(\mathrm{mg})\end{array}$ & $\begin{array}{l}\text { Riboflavin* } \\
\text { (mg) }\end{array}$ & $\begin{array}{c}\text { Nicotinic } \\
\text { acid* } \\
\text { (mg) }\end{array}$ & $\begin{array}{c}\text { Vitamin } \\
\mathrm{B}_{12}{ }^{*} \\
(\mu \mathrm{g})\end{array}$ \\
\hline $\begin{array}{l}\text { Made in a } \\
\text { village } \\
\text { Made in the }\end{array}$ & $7 \cdot 4$ & $17 \cdot 4$ & 8.6 & 0.21 & 0.05 & $3 \cdot 5$ & 0.38 \\
\hline laboratory & 5.2 & 19.7 & IIII & 0.22 & 0.16 & $3 \cdot 7$ & 0.44 \\
\hline
\end{tabular}

However, the protein value of kushik is best shown by examining its effect when included in two typical poor Iraqi meals (Table 3 ). The net dietary protein value of the first meal $(4.8 \%)$ makes it only suitable for adults, but when kushik is included the protein value reaches a level suitable for children (N.D-p.v. $=6.3 \%$ ). The protein quality of the second meal when kushik is included is high enough to satisfy the needs 
of toddlers if they eat enough to meet their energy requirement even when it is the sole source of protein (Platt, Miller \& Payne, I96ı).

Table 3. Effect of the addition of kushik on the protein value of two poor Iraqi meals

\begin{tabular}{|c|c|c|c|}
\hline Meal & $\begin{array}{c}\text { Protein } \\
\text { content } \\
(\%)\end{array}$ & $\begin{array}{l}\text { N.P.U.(op) } \\
\quad(\%)\end{array}$ & $\begin{array}{l}\text { N.D-p.v. } \\
(\%)\end{array}$ \\
\hline Rice-okra & $8 \cdot I$ & 59 & 4.8 \\
\hline Rice-okra $+15 \%$ kushik & $9 \cdot 6$ & 66 & $6 \cdot 3$ \\
\hline Parboiled wheat and 10\% chick pea & $11 \cdot 7$ & 57 & $6 \cdot 7$ \\
\hline Parboiled wheat and $10 \%$ chick pea $+15 \%$ kushik & $13 \cdot 1$ & 57 & $7 \cdot 5$ \\
\hline
\end{tabular}

Kushik can be stored for a long time. It not only improves the protein value of the two cereal diets and their palatability, but it also increases their content of $\mathrm{B}$ vitamins and calcium. At the present time kushik is produced in the home for family use only. The establishment of small factories in a village or group of villages, where there is an abundance or even a surplus of milk, as well as in areas where the supplies fluctuate from season to season, could make it more widely available. The availability of supplies of such a stable milk product at a low price in areas with an inadequate milk supply could contribute towards the solution of the problem of malnutrition in the country.

\section{REFERENCES}

Adolph, W. H. (1954). F. Amer. diet. Ass. 30, 753 .

Al Witry, H., Shaby, J. \& Kantarjian, A. D. (1950). F. Fac. Med. Iraq, 14, 143.

British Medical Association: Committee on Nutrition. (1950). Report of Committee on Nutrition. London: British Medical Association.

Demarchi, M. (1958). Amer. F. clin. Nutr. 6, 4r5.

FAO (1958). Yearbook of F.A.O. 1957. Rome: Food and Agriculture Organization of the United Nations.

Frankul, W. \& Pellett, P. L. (1959). Proc. Nutr. Soc. 18, xxxvii.

Gounelle, H. \& Demarchi, M. (r953). F. Fac. Med. Iraq, r7, 42.

Gounelle, H., Demarchi, M., Rabii, H., Rashid, R., Findakly, S., Selloumi, H. F. \& Cofman, S. (1956). Bull. Soc. Sci. Hyg. Aliment., Paris, 44, 269.

Iraq Ministry of Health. (1958). Annual Report.

Jalili, M. A. \& Demarchi, M. (1952). F. Fac. Med. Iraq, 16, 7I.

Jalili, M. A., Georges, F. \& Fadhil, A. S. (1950). F. Fac. Med. Iraq, 14, 98.

Platt, B. S., Miller, D. S. \& Payne, P. R. (196r). In Recent Advances in Human Nutrition [J. F. Brock, editor.] London: Churchill.

Salman Taj El Din \& Al Jawad, J. (1956). J. med. Prof. Baghdad, 5, 69.

Stacy, R. S. (1944). Trans. R. Soc. trop. Med. Hyg. 27, 367.

Van Veen, A. G. (1957). Formented Protein Rich Foods. F.A.O. 57/3/1966.

\section{Problems and some solutions: Pakistan}

By S. MaQsood Ali, Human Nutrition Research Unit, National Institute for Medical Research, The Ridgeway, Mill Hill, London, N.W.7

The large variety of hot, highly flavoured and sweet dishes in a Pakistani Restaurant may give casual observers a rosy picture of the dietary of the country. 